\title{
Involvement of a Recombination Repair Function in Disciplined Cell Division of Micrococcus radiodurans
}

\author{
By B. E. B. MOSELEY AND H. J. R. COPLAND \\ Department of Microbiology, University of Edinburgh, \\ School of Agriculture, Edinburgh $\mathrm{EH}_{9}{ }_{3} \mathrm{JG}$
}

(Reccived 2I August 1974)

\begin{abstract}
SUMMAR Y
When a culture of the temperature-sensitive DNA mutant Micrococcus radiodurans ts I is irradiated with a sublethal dose of ultraviolet or ionizing radiation and is plated immediately, all the bacteria give rise, after $36 \mathrm{~h}$ incubation, to colonies identical to those derived from unirradiated bacteria. However, when the irradiated population is held at its restrictive temperature $\left(39{ }^{\circ} \mathrm{C}\right.$ ) (restrictive temperature holding) for $3 \mathrm{~h}$ before being plated, less than $0.1 \%$ of the surviving bacteria give rise to normal colonies, the rest producing, after incubation for $96 \mathrm{~h}$, small malformed colonies. Qualitatively, the same effect is observed when u.v.irradiated wild-type $M$. radiodurans is incubated at $39^{\circ} \mathrm{C}$ in the presence of nalidixic acid before plating. Compared with the loss of viability, the loss of normal colony development as a function of the radiation dose is sensitive, having $\mathrm{I} / \mathrm{e}$ values of $210 \mathrm{ergs} / \mathrm{mm}^{2}$ for u.v. radiation and of 4 to $5 \mathrm{krad}$ for ${ }^{60} \mathrm{Co} \gamma$-radiation. These are identical to the radiation dose-response values of a recombinationdeficient mutant of $M$. radiodurans. At first the abnormal colonies consist entirely of giant bacteria but eventually a few bacteria with normal morphology appear and because of their much faster generation time a highly sectored colony results. These colonies can be 'rescued' by plating the irradiated bacteria held at $39^{\circ} \mathrm{C}$ on agar containing pantoyl lactone, their growth being identical to that of unirradiated bacteria. Abnormal colony development is not a general phenomenon in temperature-sensitive mutants of $M$. radiodurans but occurs in those mutants which are sensitized to radiation when held at $39{ }^{\circ} \mathrm{C}$. It is concluded that these abnormal colonies are produced as a result of a defect in a recombination function and that this function is also involved in the regulation of normal cell division.
\end{abstract}

\section{INTRODUCTION}

Wild-type Micrococcus radiodurans is extremely resistant to the lethal action of both u.v. and ionizing radiation (Anderson et al. 1956; Duggan, Anderson, Elliker \& Cain, 1959) and to chemical damage to its DNA, e.g. by $N$-methyl- $N^{\prime}$-nitro- $N$-nitrosoguanidine (NTG) (Moseley, 1967). Thus the average doses of u.v. or ionizing radiation required to inactivate a single viable unit are $12250 \mathrm{ergs} / \mathrm{mm}^{2}$ or $720 \mathrm{krad}$ respectively. The resistance of $M$. radiodurans is due, at least in part, to its ability to excise potentially lethal u.v.-induced pyrimidine dimers from its DNA (Boling \& Setlow, 1966) and to a DNA repair mechanism involving a recombination function (Moseley, Mattingly \& Copland, 1972a).

Survival in an irradiated or chemically-treated population of bacteria is usually measured by determining the proportion of bacteria able to give rise to colonies on a nutrient agar medium. In the case of $M$. radiodurans such colonies are usually identical to those derived from unirradiated bacteria, but it has been noted previously that some colonies which arise 
following treatment with X-rays (Moseley, 1963) or NTG (Moseley, 1967) were smaller and 'showed abnormalities, e.g. sectoring caused by partial loss of pigment, roughness, and growth rate variations leading to the formation of very irregular edges to the colonies'. Such abnormal colonies seemed to arise sporadically and unpredictably following irradiation of cultures and the immediate conclusion was that the treatments, being potentially mutagenic, had caused extensive mutation in the populations in the abnormal colonies. Such an interpretation has been made by Driedger (1970). However, in spite of our initial inclination to this view we have been unable to demonstrate the presence of mutants, and have an alternative explanation.

A method is described which allows an irradiated population of $M$. radiodurans to produce either normal or abnormal colonies of the type described. The abnormal colonies appear to be produced as a result of a partial defect in the recombination-type repair which, although enabling an irradiated bacterium to remain viable, causes it to give rise to grossly enlarged and distorted progeny. It probably represents the expression of a normally repressed gene similar to fil or lon in Escherichia coli (Adler \& Hardigree, 1964; Howard-Flanders, Simson \& Theriot, 1964).

\section{ME'THODS}

Bacteria. Micrococcus radiodurans wild-type; $M$. radiodurans ts I, ts2 and ts 3 , temperaturesensitive mutants defective in DNA synthesis at $39{ }^{\circ} \mathrm{C} ; M$. radiodurans ts 9 and ts I , temperature-sensitive mutants defective in cell wall synthesis at $39{ }^{\circ} \mathrm{C}$. All these strains are very resistant to the lethal action of u.v. and ionizing radiation at $30^{\circ} \mathrm{C}$ (Moseley, Mattingly \& Shimmin, 1972b; Moseley et al. 1972a).

Media. TGY medium for growth contained: Bacto-tryptone (Difco), $5 \mathrm{~g}$; glucose, I g; yeast extract (Difco), $3 \mathrm{~g}$; distilled water to $\mathrm{I} 1$. TGY agar was made by solidifying this medium with $15 \mathrm{~g}$ Bacto-agar/1. Pantoyl lactone agar was made by adding filter-sterilized pantoyl lactone solution to molten TGY agar to give a final concentration of $\mathrm{I} 2 \mathrm{~g} / \mathrm{l}(\equiv 0.09 \mathrm{M})$. The 0.067 M-phosphate buffer $\mathrm{pH} 7.0$ contained $4.73 \mathrm{~g} \mathrm{Na}_{2} \mathrm{HPO}_{4}$ and $4.54 \mathrm{~g} \mathrm{KH}_{2} \mathrm{PO}_{4}$ per I 1 distilled water.

Growth of bacteria. Bacteria were grown in $20 \mathrm{ml}$ quantities of TGY medium in $250 \mathrm{ml}$ conical flasks which were swirled at $30^{\circ} \mathrm{C}$ until the extinction of the cultures measured on a nephelometer (Evans Electroselenium Ltd, Halstead, Essex) with an orange filter, was between 0.25 and 0.30 (equivalent to $8 \times 10^{7}$ to $9 \times 10^{7}$ viable units $/ \mathrm{ml}$.).

Irradiation of bacteria. Ten $\mathrm{ml}$ samples of the bacteria were washed and resuspended in phosphate buffer at a concentration of about $10^{8}$ viable units $/ \mathrm{ml}$. For u.v. irradiation a $5 \mathrm{ml}$ sample of the washed suspension in a $9 \mathrm{~cm}$ Petri dish was agitated with a magnetic stirrer at a distance of $40 \mathrm{~cm}$ from a Hanovia model 12 germicidal lamp (incident dose rate 22.5 ergs/ $\mathrm{mm}^{2} / \mathrm{s}$ ). Viability was measured by removing $0 \cdot 1 \mathrm{ml}$ samples, suitably diluting, and spreading $0 \cdot \mathrm{I} \mathrm{ml}$ quantities on TGY plates. Colonies were counted after $36 \mathrm{~h}$ at $30^{\circ} \mathrm{C}$.

Gamma irradiation was carried out with a ${ }^{60} \mathrm{Co}$ source at a dose rate of 5 to $6 \mathrm{krad} / \mathrm{min}$. Three $\mathrm{ml}$ volumes of the washed bacterial suspension were irradiated, oxygen being bubbled during the irradiation. Viability was measured in the same way as for u.v. irradiation.

Post-irradiation treatment. Samples $(0.1 \mathrm{ml})$ of the irradiated and unirradiated cultures were diluted into $10 \mathrm{ml}$ amounts of TGY medium in $250 \mathrm{ml}$ flasks and these were incubated on reciprocating shakers immersed in water baths at 30 or $39{ }^{\circ} \mathrm{C}$ as required. The large dilution factor was used to prevent the aggregation of bacteria which often follows the irradiation of relatively dense cultures, making quantitative analysis difficult. The viability of the bacteria in these cultures was measured by removing $0.1 \mathrm{ml}$ samples at various times, 
diluting appropriately in TGY medium and plating $0 \cdot \mathbf{I} \mathrm{ml}$ samples on TGY plates. Colonies were counted after $36 \mathrm{~h}$ and again after 4 days' incubation at $30^{\circ} \mathrm{C}$. When necessary nalidixic acid or chloramphenicol solutions, sterilized by filtration, were added to the postirradiation incubation TGY medium to give final concentrations of 10 and $15 \mu \mathrm{g} / \mathrm{ml}$, respectively, before the bacteria were added.

\section{RESULTS}

\section{Effect of increasing incubation times at $39^{\circ} \mathrm{C}$ on cultures of}

Micrococcus radiodurans tSI given a single radiation dose

The result of u.v.-irradiating an exponential-phase culture of $M$. radiodurans ts I with a dose of $6600 \mathrm{ergs} / \mathrm{mm}^{2}$, resuspending it in TGY medium at its restrictive temperature of $39{ }^{\circ} \mathrm{C}$ and plating on TGY agar after varying times at $39{ }^{\circ} \mathrm{C}$ is shown in Fig. I. After incubation of the plates at $30^{\circ} \mathrm{C}$ for $36 \mathrm{~h}$ the viability of the irradiated population appeared to have fallen from nearly $100 \%$ at zero time to $0.03 \%$ after $3 \mathrm{~h}$ at $39^{\circ} \mathrm{C}$. All the colonies at this stage were similar to those derived from unirradiated bacteria. However, when the plates were re-incubated for a further $48 \mathrm{~h}$ most of the 'missing' colonies had grown but were of an abnormal type, being much smaller and highly sectored. After holding the irradiated population at $39^{\circ} \mathrm{C}$ for $3 \mathrm{~h}$ the ratio of abnormal to normal colonies was $2000: \mathrm{r}$, although this value varied somewhat from one experiment to another, the minimum ratio being about $400: \mathrm{I}$. An unirradiated population held at $39{ }^{\circ} \mathrm{C}$ showed no loss of viability for the duration of the experiment, there being an initial increase in numbers presumably because those bacteria which had just completed a round of DNA replication before being put at $39{ }^{\circ} \mathrm{C}$ could proceed to division. However, about $50 \%$ of these unirradiated bacteria held at $39{ }^{\circ} \mathrm{C}$ for $3 \mathrm{~h}$ gave abnormal colonies (see later section).

The phenomenon described was not considerably altered when the irradiated bacteria were incubated at $39{ }^{\circ} \mathrm{C}$ in TGY medium containing $x 5 \mu$ g chloramphenicol $/ \mathrm{ml}$ (Table I).

The bacteria from normal colonies had dimensions of about $2 \times 2 \times 4 \mu \mathrm{m}$ for the diplococcal stage while those from the abnormal colonies were mainly large distorted forms with typical dimensions of about $5 \times 5 \times 8 \mu \mathrm{m}$, i.e. about twelve times larger in volume. During the early development of some of the abnormal colonies (up to the 128 cell stage) only very large forms were present but from that stage an increasing number of normal-sized bacteria became apparent, usually as a fringe of cells on the side of the colony. An indication of the relative sizes of the colonies and their development and of the bacterial morphology are shown in Figs. 2 to 5. When replated on TGY agar the small sectored colonies gave rise to both normal and abnormal colonies in varying proportions.

The result of raising the u.v. dose to $10600 \mathrm{ergs} / \mathrm{mm}^{2}$, which reduced the initial viability to $50 \%$, is shown in Fig. 6 . There was a similar loss of normal colony development following exposure to $39^{\circ} \mathrm{C}$. In this case $0.04 \%$ of the initial population gave rise to normal colonies after $3 \mathrm{~h}$ at $39^{\circ} \mathrm{C}$ compared with $17 \%$ which gave abnormal colonies, i.e. a ratio of abnormal to normal colonies of about 400 : I. The maximum rate of loss of normal colony development for both doses occurred between 40 and $140 \mathrm{~min}$, i.e. the time of expression of this phenomenon was not dose-dependent.

There was a small effect on normal colony development when the wild-type strain of $M$. radiodurans was u.v.-irradiated with $\mathrm{I} 0600 \mathrm{ergs} / \mathrm{mm}^{2}$ and held for $3 \mathrm{~h}$ at $39^{\circ} \mathrm{C}$. In one such experiment the initial viability was reduced to $20 \%$, but after $3 \mathrm{~h}$ at $39^{\circ} \mathrm{C}$ approximately half of the surviving population gave normal colonies. 


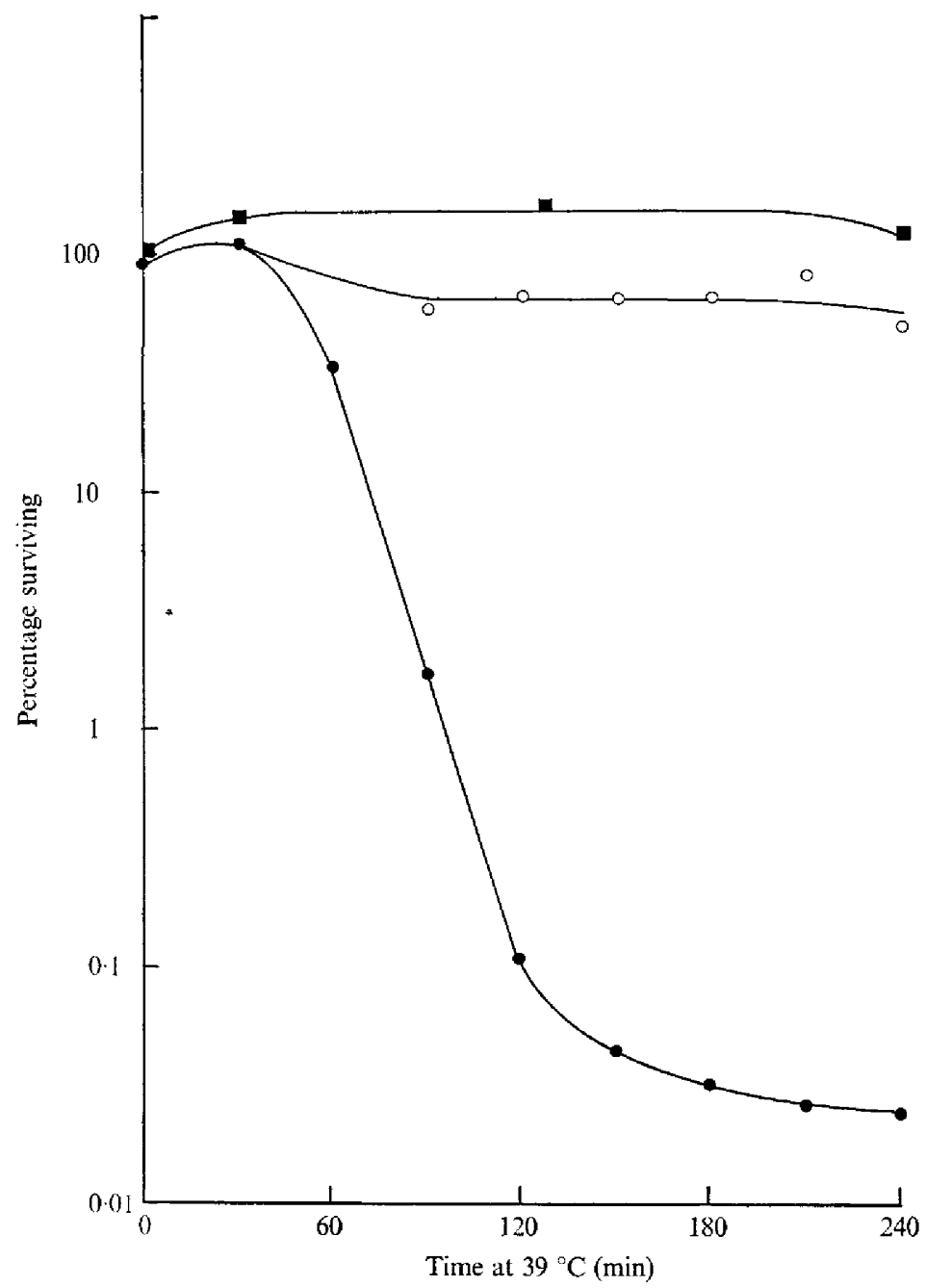

Fig. I. Normal and abnormal colony formation in u.y.-irradiated $M$. radiodurans ts I as a result of post-irradiation incubation at $39{ }^{\circ} \mathrm{C}$ (restrictive temperature holding). The irradiation dose was $6600 \mathrm{ergs} / \mathrm{mm}^{2}$. Normal colonies (O) were counted after incubation for $36 \mathrm{~h}$ and the total number (normal plus abnormal) $(O)$ after incubation for 4 days. A control culture ( $)$ was unirradiated but held at $39^{\circ} \mathrm{C}$ and scored for normal colonies.

Ionizing radiation had the same effect as u.v. radiation. The result of irradiating $M$. radiodurans ts I with $400 \mathrm{krad}{ }^{60} \mathrm{Co} \gamma$-radiation and incubating at $39{ }^{\circ} \mathrm{C}$ for increasing times is shown in Fig. 7. The results are qualitatively similar to those for u.v. radiation, the loss of normal colony development being mainly completed by $3 \mathrm{~h}$ at $39^{\circ} \mathrm{C}$.

\section{Effect of varying doses of radiation followed by incubation at $39{ }^{\circ} \mathrm{C}$}

Since the loss of normal colony development was mainly complete for different u.v. doses and for ionizing radiation after $3 \mathrm{~h}$ at $39{ }^{\circ} \mathrm{C}$, this time was chosen as an end point for studying the effect of increasing doses of radiation on the sensitivity of normal colony formation. The results for u.v. and ionizing radiation are shown in Figs. 8 and 9. Compared with the 
Table I. Effect of adding chloramphenicol ( $15 \mu \mathrm{g} / \mathrm{ml})$ to the post-irradiation incubation medium on abnormal colony formation in Micrococcus radiodurans tsI

$\begin{array}{lcc}\begin{array}{c}\text { Post-irradiation } \\ \text { treatment }\end{array} & \overbrace{\text { Normal }}^{3 \mathrm{~h} \text { at } 39^{\circ} \mathrm{C}(\%)^{*}} & \begin{array}{c}\text { Abnormal } \\ \text { Held at } 39^{\circ} \mathrm{C}\end{array} \\ \begin{array}{c}\text { Held at } 39^{\circ} \mathrm{C} \text { in presence of } \\ \text { chloramphenicol }\end{array} & 0.2 & 80 \\ \left.\text { * Taking the initial viable count (which was about } 10^{8} / \mathrm{ml}\right) \text { as } 100 \% & 63\end{array}$

loss of vability in the population as a whole, the initial loss of normal colony-forming ability was sensitive to u.v. radiation, the slope having a $1 / \mathrm{e}$ value of $2 \mathrm{IO} \mathrm{ergs} / \mathrm{mm}^{2}$, and very sensitive to ionizing radiation having a $1 / \mathrm{e}$ value of 4 to $5 \mathrm{krad}$. These values were equivalent to those for the inactivation of a recombination-deficient mutant (rec3o) of $M$. radiodurans. The isolation and characterization of this mutant is to be the subject of another publication but the radiation dose-response curves have been superimposed on the data of Figs. 8 and 9. The loss of normal colony development, initially sensitive to both forms of radiation, became refractory and further loss was a function of the loss of viability in the population as a whole.

\section{The effect of post-irradiation incubation of wild-type Micrococcus radiodurans at $39^{\circ} \mathrm{C}$ in the presence of nalidixic acid}

The effect of raising the temperature of $M$. radiodurans ts 1 to $39^{\circ} \mathrm{C}$ is to inhibit DNA synthesis while allowing RNA and protein synthesis to continue (Moseley et al. $1972 b$ ). We therefore investigated the effect of inhibiting DNA synthesis on colony formation in the wild-type strain of $M$. radiodurans using nalidixic acid under comparable conditions. Qualitatively the same effect was observed, but it was less marked than in the case of $M$. radiodurans tsi. Following a u.v.-irradiation dose of $10600 \mathrm{ergs} / \mathrm{mm}^{2}$ the loss of normal colony development was less rapid, occurring between 60 and $210 \mathrm{~min}$, normal colonies being produced by $0.2 \%$ and abnormal colonies by $28 \%$ of the original population. Unfortunately, nalidixic acid was not a good inhibitor of DNA synthesis in $M$. radiodurans because although DNA synthesis is $80 \%$ inhibited in the presence of $2 \mu \mathrm{g}$ nalidixic acid $/ \mathrm{ml}$, increasing the concentration to $200 \mu \mathrm{g} / \mathrm{ml}$ does not cause much further inhibition (Driedger \& Grayston, I97I). Incubation of irradiated cells in nalidixic acid at $30^{\circ} \mathrm{C}$ had almost no effect on colony development, at least $90 \%$ giving rise to normal colonies.

A comparison of various treatments of irradiated and unirradiated strains of $M$. radiodurans on abnormal colony development is shown in Table 2.

\section{The effect of pantoyl lactone on rescuing abnormal colonies}

The effect of plating irradiated wild-type $M$. radiodurans, held for increasing times at $39{ }^{\circ} \mathrm{C}$ in TGY broth containing nalidixic acid, on TGY agar containing pantoyl lactone ( $12 \mathrm{mg} / \mathrm{ml}$ ) is shown in Fig. IO. The addition of pantoyl lactone to the medium slightly reduced the size of colonies from unirradiated bacteria but nevertheless 'rescued' the colonies which in its absence would have taken four days to develop and would have been highly sectored. In the presence of pantoyl lactone all the colonies appeared after incubation at $30^{\circ} \mathrm{C}$ for $36 \mathrm{~h}$ and were indistinguishable from colonies derived from unirradiated bacteria. All the bacteria in these colonies had normal morphology. 

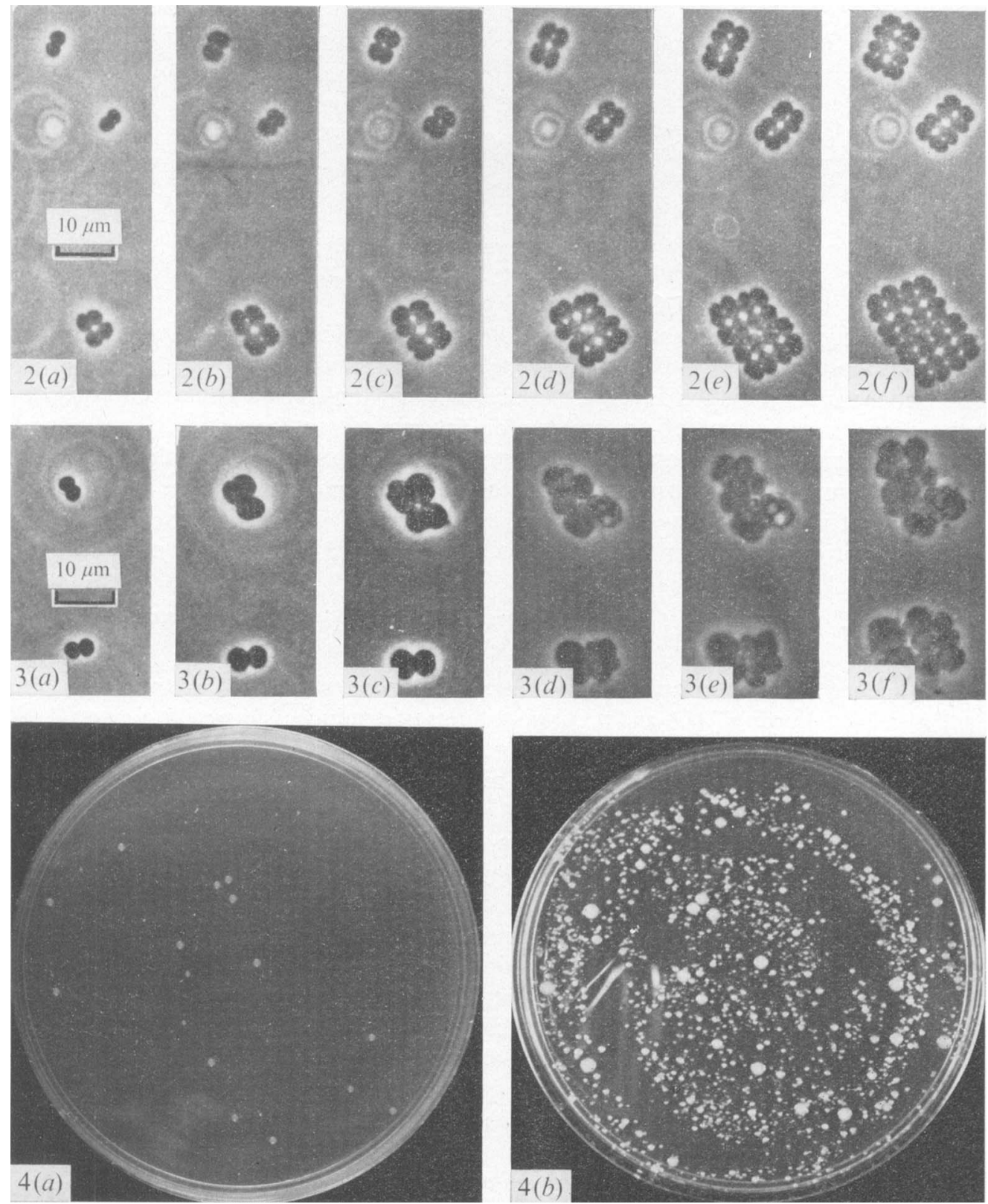

Fig. 2. Stages in the early development of a normal colony of $M$. radiodurans tst. The sequence, $(a)$ to $(f)$, was photographed over a $4 \mathrm{~h}$ period.

Fig. 3. Stages in the early development of an abnormal colony of $M$. radiodurans tsi. The sequence, (a) to $(f)$, was photographed over a $12 \mathrm{~h}$ period.

Fig. 4. A culture of $M$. radiodurans tsi, u.v.-irradiated $\left(6600 \mathrm{ergs} / \mathrm{mm}^{2}\right)$ and held at $39^{\circ} \mathrm{C}$ for $3 \mathrm{~h}$ before plating. (a) This plate had been incubated at $30^{\circ} \mathrm{C}$ for $48 \mathrm{~h}$ and had 15 normal colonies; the abnormal colonies are just visible. (b) The same plate after incubation at $30^{\circ} \mathrm{C}$ for 4 days. The number of colonies, based on counts at higher dilutions, is about 5000. 

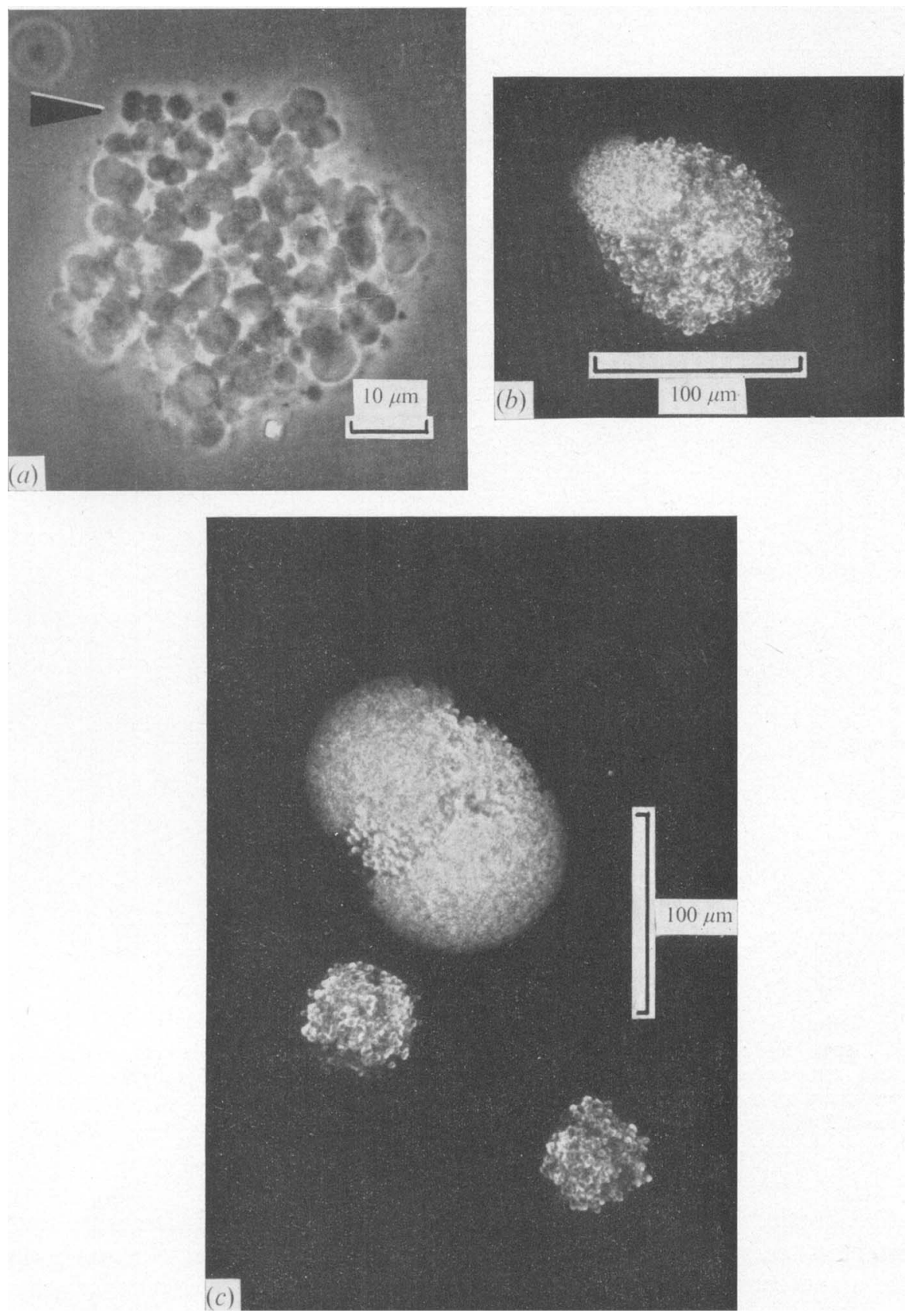

Fig. 5. Abnormal colony development. (a) The arrow indicates a tetrad of bacteria with normal morphology on the colony edge. $(b),(c)$ The normal-sized bacteria have given rise to sectors which are now growing faster than the portion of the colony occupied by 'giant' cells. 


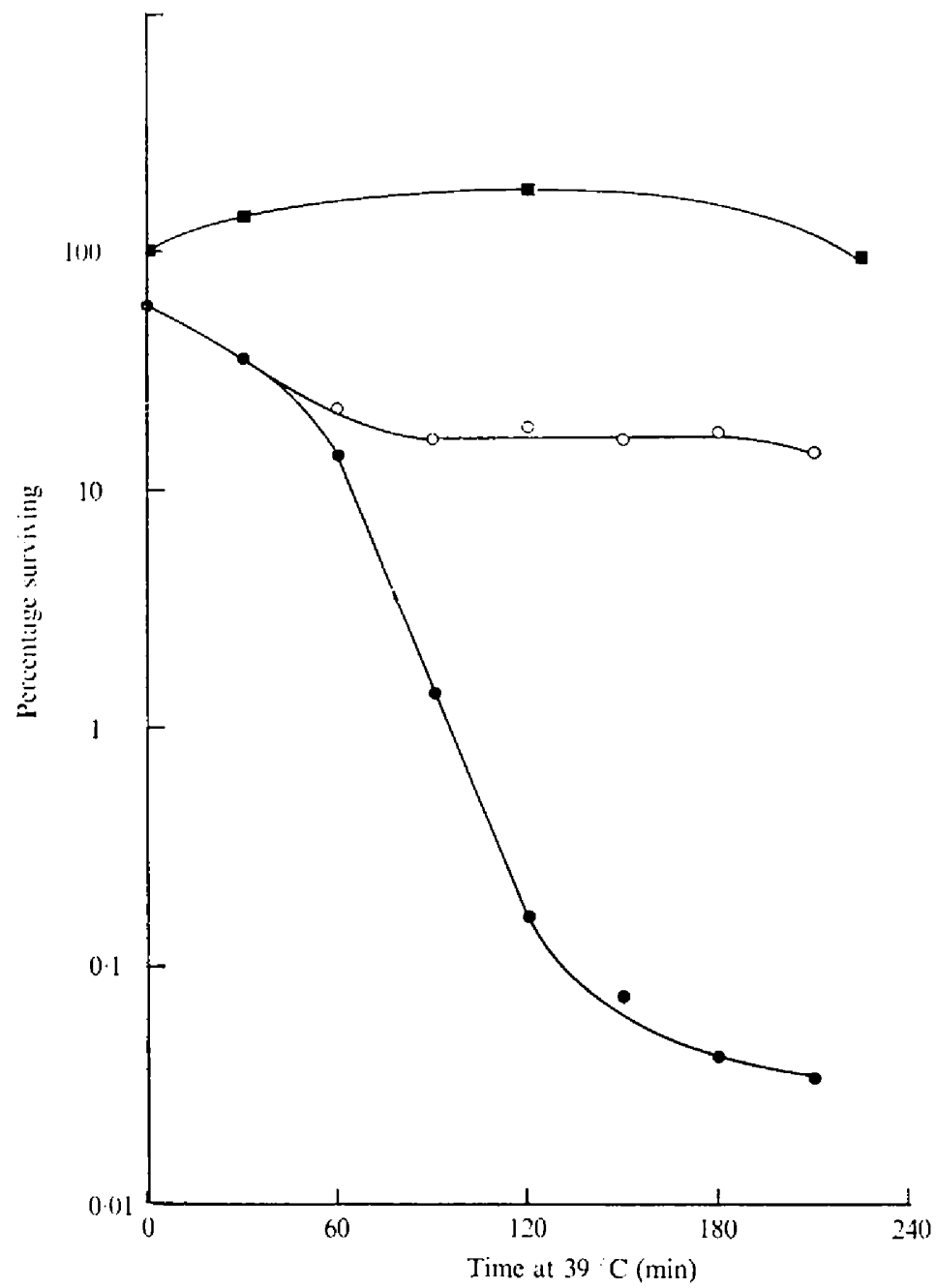

Fig. 6. Normal and abnormal colony formation in u.v.-irradiated $M$. radiodurans ts I as a result of restrictive temperature holding. The irradiation dose was $10600 \mathrm{ergs} / \mathrm{mm}^{2}$. The number of normal (O) and the total number (normal plus abnormal) (O) of colonies were counted after incubation for $36 \mathrm{~h}$ and 4 days respectively. A control culture ( $\mathrm{D}$ ) was unirradiated but subjected to restrictive temperature holding and scored for normal colonies.

The effect of pantoyl lactone on the recovery of irradiated $M$. radiodurans ts I could not be investigated because the bacteria did not form colonies on agar containing pantoyl lactone at a concentration of $12 \mathrm{mg} / \mathrm{ml}$. This strain did form colonies on agar containing $3 \mathrm{mg}$ pantoyl lactone $\mathrm{ml}$ but at this concentration pantoyl lactone had no rescuing effect on the abnormal colonies of either $M$. radiodurans ts I or the wild-type. Spontaneous mutants of ts I selected for resistance to pantoyl lactone ( $2 \mathrm{mg} / \mathrm{ml}$ ) were also temperature-resistant (four out of four) and all spontaneous mutants selected for temperature-resistance were pantoyl lactone-resistant (eleven out of eleven). This surprised us. Since $M$. radiodurans ts I can be transformed to temperature resistance with wild-type DNA at a frequency associated with a single marker, it is assumed that the same locus controls both properties in this 


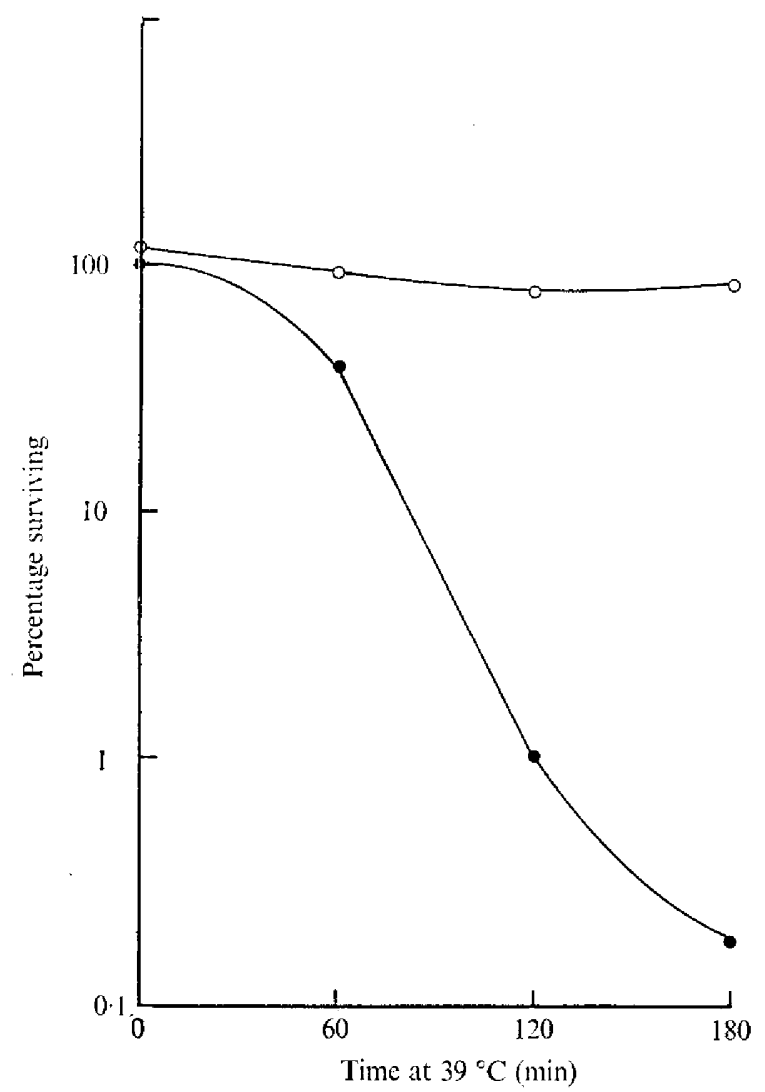

Fig. 7. Normal and abnormal colony formation in ${ }^{60} \mathrm{Co} \gamma$-irradiated $M$. radiodurans ts $\mathrm{I}$ as a result of restrictive temperature holding. The irradiation dose was $400 \mathrm{krad}$. Normal colonies $(\boldsymbol{O})$ and the total number of colonies (normal plus abnormal) $(O)$ were counted after incubation for $36 \mathrm{~h}$ and 4 days respectively.

mutant but that the permissive temperature for growth in pantoyl lactone is lower than for DNA synthesis. Micrococcus radiodurans ts2 mutant in another locus which affects DNA synthesis is able to grow on agar containing $12 \mathrm{mg}$ pantoyl lactone/ $\mathrm{ml}$ and gives the same results as the wild type, viz. pantoyl lactone rescues abnormal colonies formed as a result of holding the bacteria at $39^{\circ} \mathrm{C}$.

\section{Effect of holding irradiated populations at $39{ }^{\circ} \mathrm{C}$ for $3 \mathrm{~h}$ on other temperature-sensitive mutants of $M$. radiodurans}

Several temperature-sensitive mutants of $M$. radiodurans were tested for the loss of normal colony development by u.v.-irradiating exponential-phase populations with a dose of 6600 ergs $/ \mathrm{mm}^{2}$ and plating after $3 \mathrm{~h}$ at $39^{\circ} \mathrm{C}$. The proportion of surviving bacteria which gave rise to normal colonies is shown in Table 3. The effect described for tsI is also true for the mutant ts 2 but not for the mutants ts 3 , ts9 or tsi I. Some other properties of these mutants relevant to the loss of normal colony development are included in the Table. Those mutants which gave predominantly normal colonies, i.e. ts 3 , ts 9 and ts $r x$, were not sensitized to radiation when held at their restrictive temperatures, while ts I and ts2, which gave 


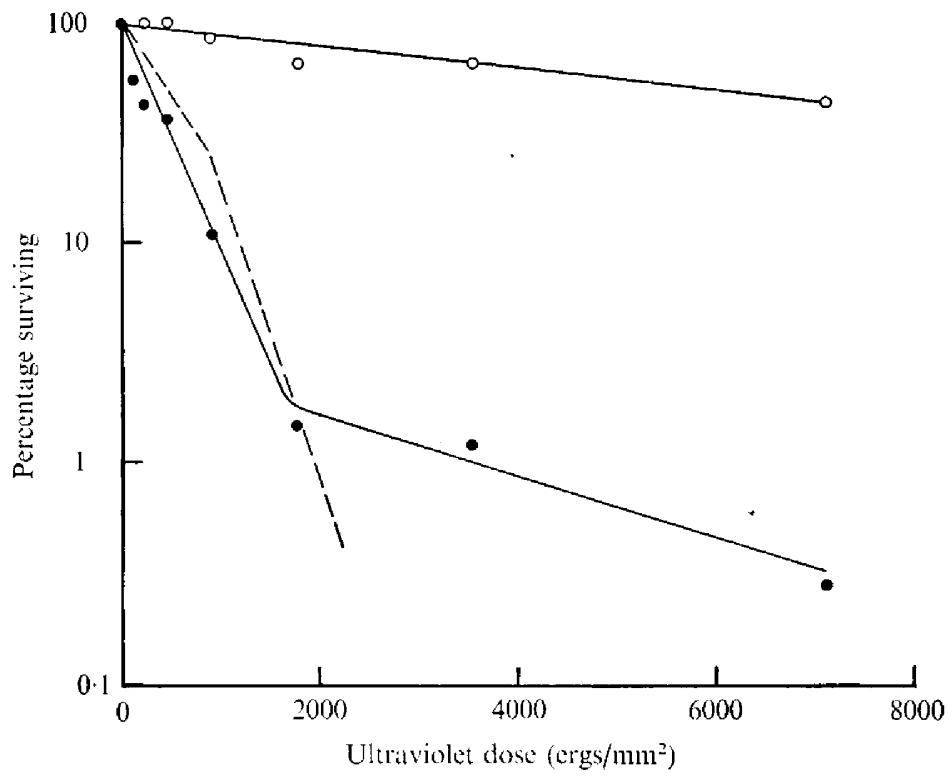

Fig. 8. Ultraviolet radiation dose-response curve for survival of normal colony-forming ability in $M$. radiodurans ts I subjected to restrictive temperature holding for I $80 \mathrm{~min}$ after irradiation. Normal colonies $(O)$ and the total number of colonies $(O)$ were counted after $36 \mathrm{~h}$ and 4 days respectively. The dose-response curve for survival of a recombination-deficient mutant of $M$. radiodurans (rec3o) is included for comparison (broken line).

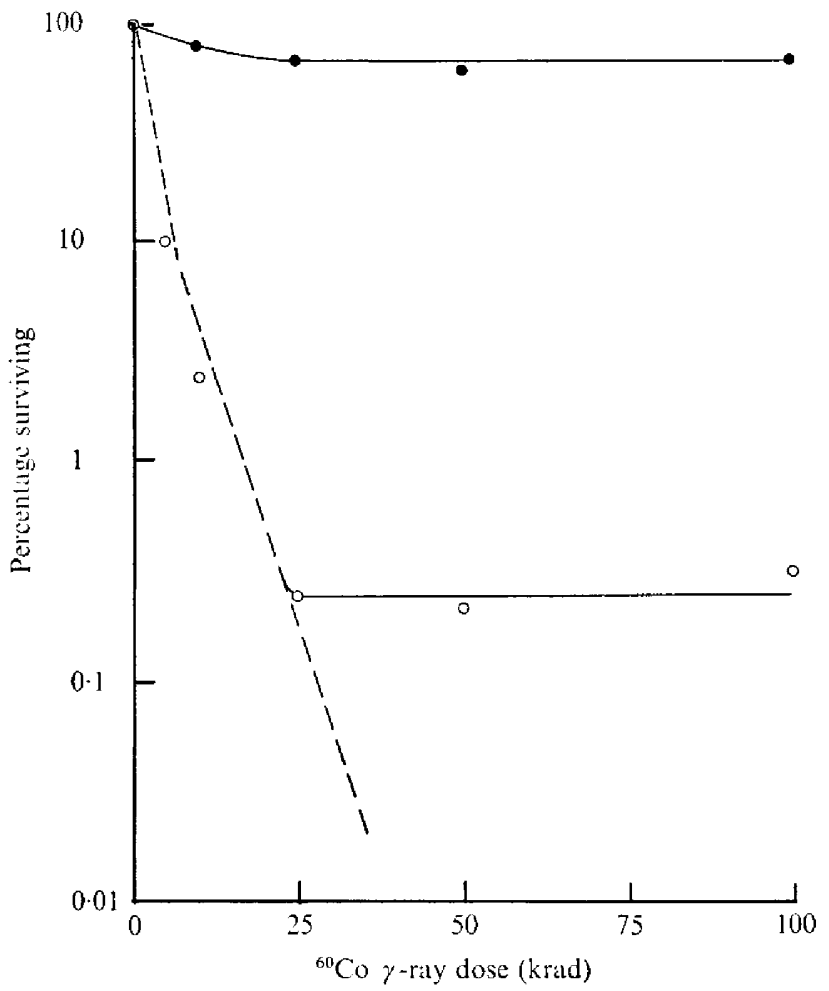

Fig. 9. Ionizing radiation dose-response curve for survival of normal colony-forming ability in $M$. radiodurans ts I subjected to restrictive temperature holding for $180 \mathrm{~min}$ after irradiation. Normal colonies (O) and the total number of colonies (O) were scored after incubation for $36 \mathrm{~h}$ and 4 days respectively. The dose-response curve for survival of a recombination-deficient mutant of $M$. radiodurans (rec3o) is included for comparison (broken line). 
Table 2. Effect of various incubation conditions on normal colony development in $M$. radiodurans

\begin{tabular}{|c|c|c|c|c|}
\hline $\begin{array}{l}\text { Strain of } \\
M, \text { radiodurans }\end{array}$ & $\begin{array}{l}\text { Irradiation dose } \\
\quad\left(\mathrm{ergs} / \mathrm{mm}^{2}\right)\end{array}$ & $\begin{array}{c}\text { Incubation } \\
\text { temperature* } \\
\left({ }^{\circ} \mathrm{C}\right)\end{array}$ & $\begin{array}{l}\text { Nalidixic } \\
\text { acid present }\end{array}$ & $\begin{array}{l}\text { Percentage of } \\
\text { survivors } \\
\text { giving } \\
\text { normal } \\
\text { colonies }\end{array}$ \\
\hline ts I & 0 & 30 & + & 94 \\
\hline tSI & 0 & 39 & - & 40 \\
\hline ts I & 6600 & 30 & - & IOO \\
\hline tSI & 6600 & 30 & + & 82 \\
\hline ts 1 & 6600 & 39 & - & 0.43 \\
\hline Wild-type & 6600 & 39 & - & 100 \\
\hline Wild-type & 6600 & 39 & + & 2 \\
\hline
\end{tabular}

* All incubations were for $3 \mathbf{h}$.

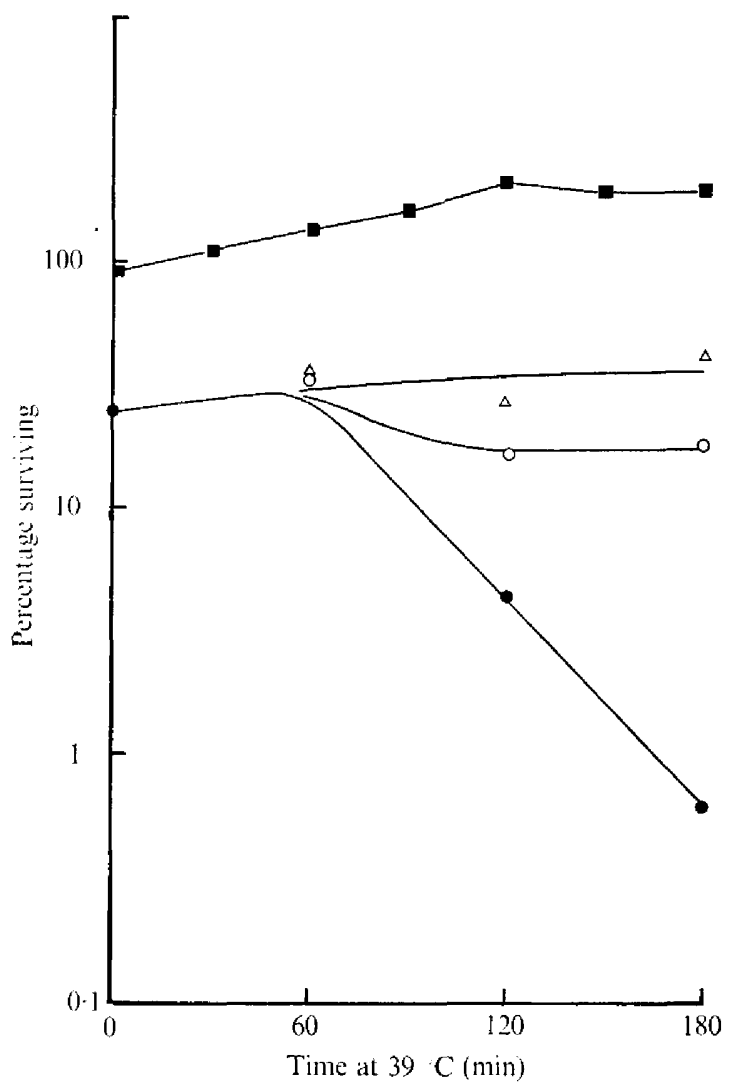

Fig. Io. Normal and abnormal colony formation in u.v.-irradiated wild-type $M$. radiodurans as a result of restrictive temperature holding in the presence of nalidixic acid, and the effect of plating on pantoyl lactone agar. The irradiation dose was $10600 \mathrm{ergs} / \mathrm{mm}^{2}$. Normal ( $)$ and total (O) colonies in the absence of pantoyl lactone were counted after incubation for $36 \mathrm{~h}$ and 4 days respectively. Normal colonies $(\triangle)$ in the presence of pantoyl lactone were counted after $36 \mathrm{~h}$ incubation. An unirradiated culture ( $)$ was held at $39^{\circ} \mathrm{C}$ in the presence of nalidixic acid and scored only for normal colonies. 


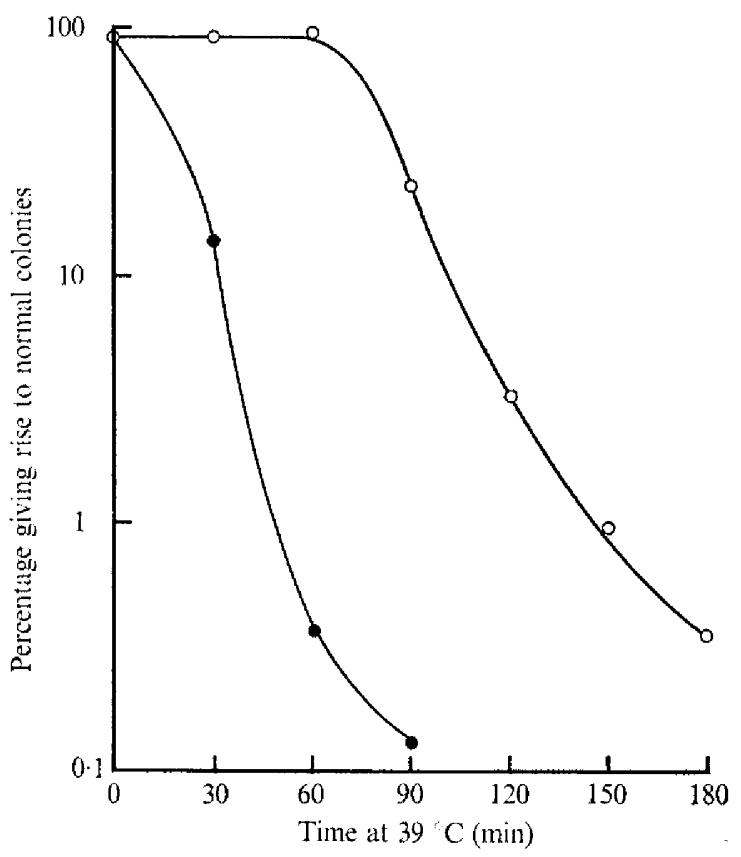

Fig. I I. Effect of restrictive temperature holding before u.v.-irradiation on normal colony-forming ability in Micrococcus radiodurans ts 1 . One culture $(O)$ was irradiated after growth at $30{ }^{\circ} \mathrm{C}$, then held at $39^{\circ} \mathrm{C}$. A second culture (O) was held at $39^{\circ} \mathrm{C}$ for $75 \mathrm{~min}$, irradiated, and held at $39^{\circ} \mathrm{C}$. The irradiation dose was $2650 \mathrm{ergs} / \mathrm{mm}^{2}$. Only the results for normal colonies are shown. The total number of colonies did not fall below $60 \%$.

Table 3. Effect on colony type of holding u.v.-irradiated populations $\left(6600 \mathrm{ergs} / \mathrm{mm}^{2}\right)$ of temperature-sensitive mutants of $M$. radiodurans at $39^{\circ} \mathrm{C}$ for $\mathrm{I} 80 \mathrm{~min}$ before being plated

\begin{tabular}{clccr} 
Mutant & \multicolumn{1}{c}{ ts defect } & Survival $(\%)$ & $\begin{array}{c}\text { Percentage of } \\
\text { survivors } \\
\text { giving normal } \\
\text { colonies }\end{array}$ & $\begin{array}{r}\text { Population } \\
\text { sensitized } \\
\text { radiation } \\
\text { holding at }\end{array}$ \\
ts & DNA synthesis & 68 & 0.12 & + \\
ts2 & DNA synthesis & 72 & 0.66 & + \\
ts3 & DNA synthesis & 74 & 83 & - \\
ts9 & Cell wall & 58 & 76 & - \\
tsI & Cell wall & 98 & 100 & -
\end{tabular}

predominantly abnormal colonies, were sensitized to radiation when held at $39{ }^{\circ} \mathrm{C}$ (Moseley et al. 1972).

\section{Effect of holding $M$. radiodurans tsI at $39^{\circ} \mathrm{C}$ before irradiation}

Since the loss of normal colony-forming ability is associated with those strains of $M$. radiodurans which are sensitized to radiation when subject to restrictive temperature holding, it was assumed that the loss of normal cell division was the result of the decay of a recombination function which also leads to sensitization. If so, the time of expression of loss of normal colony-forming ability should depend on the length of time the bacteria have been at $39{ }^{\circ} \mathrm{C}$ and not on the timing of the irradiation. A log-phase culture of $M$. radiodurans ts I grown at $30^{\circ} \mathrm{C}$ was held at $39{ }^{\circ} \mathrm{C}$ for $75 \mathrm{~min}$, irradiated, diluted into TGY medium and 
returned to $39{ }^{\circ} \mathrm{C}$. A control culture was irradiated after growth at $30^{\circ} \mathrm{C}$ and then held at $39^{\circ} \mathrm{C}$. Samples were taken from both cultures at various times, plated on TGY agar and incubated at $30^{\circ} \mathrm{C}$. Normal and abnormal colonies were counted after $36 \mathrm{~h}$ and 4 days respectively (Fig. II). Since the initial period at $39^{\circ} \mathrm{C}$ sensitizes the bacteria to radiation (Moseley et al. 1972a) the dose of u.v. radiation was kept relatively low, at $2650 \mathrm{ergs} / \mathrm{mm}^{2}$. In the culture held at $39^{\circ} \mathrm{C}$ for 75 min before irradiation, the loss of the ability to give rise to normal colonies began immediately after irradiation and occurred about $75 \mathrm{~min}$ earlier (measured from the time of irradiation) than in the control culture.

\section{DISCUSSION}

Micrococcus radiodurans can be induced to form giant cells which give rise to abnormal colonies. The maximum loss of normal colony formation occurs in irradiated populations of $M$. radiodurans in which DNA synthesis is inhibited at $39^{\circ} \mathrm{C}$. Inhibition of DNA synthesis at $30^{\circ} \mathrm{C}$ or holding strains with temperature-resistant DNA synthesis at $39^{\circ} \mathrm{C}$ does not lead to any significant loss of normal colony development.

Since the formation of abnormal colonies is enhanced by irradiation with either u.v. or ionizing radiation, what mechanism related to the repair of both forms of damage occurs in ts I held at $39^{\circ} \mathrm{C}$ ? The most likely repair mechanism which operates both for u.v. and ionizing radiation damage is that involving recombination (Rupp \& Howard-Flanders, I968), the excision process making very little contribution to the repair of ionizing radiation damage (Howard-Flanders, Theirot \& Stedeford, I969). In an unirradiated population of ts I at $39^{\circ} \mathrm{C}$, after an initial lag of about 20 min there is an exponential loss of a recombination function and the culture becomes progressively more sensitive to u.v. or ionizing radiation, leading eventually to the loss of the shoulders from the dose-response curves (Moseley et al. 1972a) which is not prevented by the presence of chloramphenicol. This suggested that the large shoulder of the survival curves is due to a repair system involving recombination.

That the loss of this recombination function plays a role in the formation of the giant bacteria and hence abnormal colonies is based on three observations. Firstly, the formation of abnormal colonies by the majority of surviving bacteria is found in the temperaturesensitive DNA mutants ts I and ts2, which both become sensitized to irradiation at $39{ }^{\circ} \mathrm{C}$ as a result of the loss of a recombination function, but is not found in the temperaturesensitive DNA mutant ts 3 or in the temperature-sensitive wall mutants ts9 and ts I I, none of which are sensitized to radiation by being held at $39{ }^{\circ} \mathrm{C}$ (Moseley et al. 1972a). An anomaly arises in the case of $M$. radiodurans ts 3 , which is unable to synthesize DNA at $39{ }^{\circ} \mathrm{C}$ but does not form abnormal colonies when subjected to restrictive temperature holding. However, it is also not sensitized to radiation by restrictive temperature holding (Moseley et al. I972 a) suggesting that either the recombination function does not decay at $39^{\circ} \mathrm{C}$ in this mutant or, more likely, that it is not defective in the step of DNA synthesis which is involved in the restrictive temperature holding effect and which presumably is sensitive to nalidixic acid. Secondly, the expression of abnormal colony formation depends on the time the culture of ts $\mathrm{I}$ has been held at $39^{\circ} \mathrm{C}$ and is independent of the timing of the irradiation. Thirdly, the loss of normal colony development as a function of irradiation dose is similar to the dose-response curves of a recombination-deficient mutant (rec3o) but not to any of the other ten radiation-sensitive mutants we possess. Thus the region of the survival curves (Figs. 8 and 9) where colonies are abnormal is that part which is absent in the recombination deficient mutant. We conclude that the recombination events which lead to survival are not 
absent but temporarily defective. Since the loss of the recombination function is dependent only on the length of time the bacteria are held at $39^{\circ} \mathrm{C}$, it is not surprising that the rate of loss of normal colony development is independent of the irradiation dose. It also follows that since inhibition of protein synthesis by chloramphenicol does not prevent the loss of the recombination function at $39{ }^{\circ} \mathrm{C}$, it does not prevent the loss of normal colony-forming ability.

Recombination functions have been implicated in the process of cell division in Escherichia coli. Thus mutation in the lon or fil gene causes irradiated cells to form long filaments in recombination-proficient bacteria (Adler \& Hardigree, 1964). A second mutation in the $\operatorname{rec} A$ gene however suppresses this effect so that after irradiation little or no filamentation is observed (Green, Greenberg \& Donch, 1969). Inouye (1971), using a rec $A$ thy strain of $E$. coli, showed that under conditions where DNA synthesis was inhibited, either by thymine deprivation or by the presence of nalidixic acid, the RecA phenotype uncoupled cell division from DNA replication so that cell division continued, eventually producing cells containing no DNA. The situation is different in Micrococcus radiodurans. In the normal bacterium the recombination function, and not its absence, suppresses the tendency to produce giant bacteria and a reduction in its level does not uncouple DNA replication and cell division since the bacteria enlarge enormously but do not divide in the absence of DNA synthesis. It is, of course, possible that the recombination lesion in ts I after $39^{\circ} \mathrm{C}$ incubation is more akin to the recB or recC lesion of $E$. coli.

The presence of pantoyl lactone in the plating medium causes surviving bacteria which would otherwise have given rise to abnormal colonies to give normal colonies. In $E$. coli, strains which have an unsuppressed $l o n$ or $f l$ gene and form long filaments after u.v. irradiation, leading to loss of viability, can be rescued by plating on pantoyl lactone agar when they are induced to form septa. The mechanism by which pantoyl lactone excrts this effect is unknown. We conclude that $M$. radiodurans is inherently capable of forming giant cells following DNA damage, equivalent to the expression of lon or fil in $E$. coli, but that it is normally repressed by a recombination function.

We thank Miss Diana Sweet for helpful criticism and valuable discussion in preparing the text. This work was supported by a grant from the Medical Research Council.

\section{REFERENCFS}

Adeer, H. I. \& Hardigree, A. A. (1964). Analysis of a gene controlling cell division and sensitivity to radiation in Escherichia coli. Journal of Bacteriology 87, 720-726.

anderson, A. W., Nordan, H. C., Cain, R. F., Parkish, G. \& Duggan, D. (I956). Studies on a radioresistant micrococcus. Isolation, morphology, cultural characteristics, and resistance to gamma radiation. Food Technology 10, $575 \cdot 57^{8}$.

Boling, M. E. \& Setlow, J. K. (1966). The resistance of Micrococcus radiodurans to ultraviolet radiation. III. A repait mechanism. Biochimica et biophysica acta 123, 26-33.

Driedger, A. A. (1970). The ordered growth pattern of microcolonies of Micrococcus radiodurans; first generation sectoring of induced lethal mutations. Canadian Journal of Microbiology 16, I I 33-1 I 35.

Drielogr, A. A. \& Grayston, M. J. (197I). The effects of nalidixic acid on X-ray induced DNA degradation and repair in Micrococcus radiodurans. Canadian Journal of Microbiology I7, 50I-505.

Dugian, D. E., Andfrsox, A. W., Elliker, P. R. \& Cain, R. F. (1959). Uitraviolet exposure studies on a gamma radiation resistant micrococcus isolated from food. Food Research 24, 376-382.

Green, M. H. L., Greenberg, J. \& Donch, J. (1969). Effect of a recA gene on cell division and capsular polysaccharide production in a lon strain of Escherichia coli. Genetical Research 14, 159-162.

Howarid-Fi.anders, P., Simson, F. \& Theriot, L. (1964). A locus that controls filament formation and sensitivity to radiation in Escherichia coli K-12. Genetics 49, 237-246. 
Howard-Flanders, P., Theriot, L. \& Stedeford, J. B. (i969). Some properties of excision-defective recombination-deficient mutants of Escherichia coli $\mathrm{K} 12$. Journal of Bacteriology 97, I134-114I.

INOUYE, M. (197I). Pleiotropic effect of the rec $A$ gene of Escherichia coli: uncoupling of cell division from deoxyribonucleic acid replication. Journal of Bacteriology 106, 539-542.

Moseley, B. E. B. (1963). The variation in X-ray resistance of Micrococcus radiodurans and some of its less pigmented mutants. International Journal of Radiation Biology 6, 489.

Moseley, B. E. B. (1967). The isolation and some properties of radiation-sensitive mutants of Micrococcus radiodurans. Journal of General Microbiology 49, 293-300.

Moseley, B. E. B., Matingly, A. \& Copland, H. J. R. (1972a). Sensitization to radiation by loss of recombination ability in a temperature-sensitive DNA mutant of Micrococcus radiodurans held at its restrictive temperature. Journal of General Microbiology 72, 329-338.

Moseley, B. E. B., Mattingly, A. \& Shimmin, M. (1972b). Isolation and some properties of temperaturesensitive mutants of Micrococcus radiodurans defective in DNA synthesis. Journal of General Microbiology 7o, 399-409.

Rupp, W. D. \& Howard-Flanders, P. (1968). Discontinuities in the DNA synthesized in an excision defective strain of Escherichia coli following ultraviolet irradiation. Journal of Molecular Biology 31, 29 1-304. 